\section{SOCIETY FOR APPLIED BACTERIOLOGY}

$\mathrm{A}^{\mathrm{T}}$

$\mathrm{T}$ the annual summer conference of the Society of Agricultural Bacteriologists, which was held at the Midland Agricultural College during July 23-25, plans were approved for a change in the title and range of interests of the Society. It has now been renamed the Society for Applied Bacteriology.

For some years the Society has, in fact, ceased. to confine its interests entirely to the agricultural field and has attracted to its membership bacteriologists working in such fields as water supplies, sewage disposal, fisheries, food manufacture and various industries, as well as those in academic institutions whose work brings them into contact with the applied aspects of the subject. The inauguration recently of the Society for General Microbiology has fortunately provided a common meeting-ground for the discussion, by microbiologists working in all fields, of the more fundamental aspects of the science. There is, however, a large number of bacteriologists for whom hitherto no adequate society has existed, and whose needs are only partially satisfied by discussions at the 'fundamental' level. At a time when scientific men are being called upon more than ever to contribute to improvements and new processes in various industries, it is essential that those working in applied bacteriology should have facilities for meeting and discussing matters of mutual interest.

Membership of the Society for Applied Bacteriology is open to all who are interested in bacteriological problems. It is intended to hold an annual conference in the summer at different centres in the British Isles, and a shorter meeting in London in the winter. For the time being, papers, or abstracts of papers, will be published in the Proceedings of the Society. It is hoped that eventually the Society's publication will increase to the size of a journal. The officers of the Society are: President: Dr. L. A. Allen, Water Pollution Research Laboratory, Watford; Secretary : Mr. D. A. McKenzie, Provincial Laboratory, 36 Otley Road, Leeds ; Treasurer : Mr. L. J. Meanwell, United Dairies (Wholesale), Ltd., Ellesmere ; Editor : Mr. A. Rowlands, National Institute for Research in Dairying, Shinfield, Reading. The annual subscription is at present one guinea.

A survey of the papers at the summer conference follows.

A paper dealing with the teaching of bacteriology emphasized its unassailable claim to be taught as a science; its students are trained as bacteriologists in the widest sense, able to apply their knowledge and experience to any and every problem of a bacteriological nature, and not restricted to the relatively narrow field of its applications to some other science. With this ideal in view, a plea was made for the establishment at universities of independent depart. ments of bacteriology, with the provision of a science degree, or at least a diploma, in bacteriology. A suitable curriculum was outlined together with observations on the teaching methods that should be applied, a distinction being drawn between the requirements of those intending to follow a career in bacteriology, and others for whom a knowledge of its applications in their own particular sphere was the only essential.

The origin and development of the National Collection of Type Cultures was described, together with an account of its organization and work. In view of the facilities now provided for the microbiologist by the type culture collections, their future is of considerable importance, and the problem was thoroughly discussed.

A contribution dealing with bacterial growth in aerated and quiescent flax infusion described the chemical changes produced. With quiescent cultures, the liquor obtained is acidic in nature, frequently containing appreciable amounts of volatile acids. Industrially, such a liquor tends to be evil-smelling, difficult to treat for purposes of disposal, and unsuitable for re-use in an industrial process. With aerated cultures, on the other hand, the reaction tends to become alkaline, with a much smaller and sometimes negligible content of volatile acids. Reduction of the organic carbon content, which as shown by the carbon balance sheet can be accounted for by the carbon dioxide produced by bacterial action, is reflected in a reduction of the polluting strength as shown by the usual methods of measurement.

A study of the microflora of immersion brines emphasized the many problems that require elucidating, not only as regards the curing process itself, but also as regards the bacteriological technique to be applied in studying the bacteria involved.

Water supplies used for dairy purposes at many Welsh farms and dairies were shown to be heavily polluted, and their purification by chlorination has been investigated. The residual bacterial flora of tap, well and clear river water was in all cases negligible following treatment for $\frac{1}{2} \mathrm{hr}$. with 10 p.p.m. chlorine. A 2 hr.-contact period using 50 p.p.m. chlorine was necessary to attain similar results with turbid river water. False-positive presumptive coliform results obtained with chlorinated stream water were caused by an organism resembling Bacillus polymyxa.

Further evidence of the value of a modified Hotis test (plating Hotis-positive samples on crystal violet blood agar), not only in reducing the work involved, but also in increasing the number of positive samples, was adduced from the results of the examination of 639 quarter samples known to be, or suspected of being, infected with Streptococcus agalactioe.

Methods for the bacteriological examination of milk continue to receive much attention. In a discussion of the choice of a suitable yardstick for evaluating tests, it was pointed out that no single test at present available is adequate to cover the whole range of producer, distributor and consumer requirements. A further paper dealt with the effect of temperature variations in the region of $37.5^{\circ} \mathrm{C}$. on the reduction of methylene blue and resazurin in milk. Results show that at temperatures between $31^{\circ} \mathrm{C}$. and $43^{\circ} \mathrm{C}$., the acceleration of reducing action and the gradual inhibition of bacterial growth in milk by increasing temperatures more or less cancel out, mean differences in reduction times being well inside the experimental error of about $\frac{1}{2} \mathrm{hr}$.

With the introduction of the National Milk Testing and Advisory Scheme, bacteriological tests and standards for the examination of washed churns were prescribed. Towards the end of 1944, 5,400 churns at 1,110 milk depots in England and Wales were being tested monthly by these methods. Results obtained in Wales showed that mechanically washed churns were, in general, bacteriologically more satisfactory than those washed by hand and then steamed over a jet, although at dairies dealing with a small number of churns daily (less than fifty), which allows of adequate time for steaming both lids and churns, equally satisfactory results were obtained. 
The effect of contamination from churns on the bacteriological and keeping quality of both raw and pasteurized milk was the subject of another paper. There is in general no measurable effect, unless the number of bacteria added by the churns is at least equal to that initially present in the milk. Churns which have been mechanically washed efficiently are without effect on the keeping quality of the milk, and no advantage accrues from further steam sterilization of such churns.

The Proceedings of the Society, containing full abstracts of the papers read at the conference, may be purchased from the honorary treasurer.

\section{BRITISH ELECTRICAL ENGINEERS AND THE WAR}

$\mathbf{A}^{\mathrm{T}}$ $T$ the opening meeting on October 4 of the current session of the Institution of Electrical Engineers, Dr. P. Dunsheath delivered his presidential address, in the course of which he gave a broad survey of some of the contributions made by British electrical engineers to the successful outcome of the greatest war in history. The scope of the address was very wide and covered such subjects as the maintenance of the electric power supply of Great Britain, the considerable increase in communications both at home and overseas, the use of broadcasting and radar as defensive and offensive weapons, the defeat of the magnetic mine, radio aids to navigation and gun-laying, the improvement of searchlights and the development of electrical equipment for research on atomic energy. The success attained in all this work was in no small measure due to the extensive and ready co-operation which was built up between the Services and the electrical industry for the purpose of solving the many problems of design and production which continually arose. In giving some general facts about the above contributions, Dr. Dunsheath disclosed some striking figures concerning the various phases of electrical engineering as adapted to war-time requirements.

The problem of the maintenance of an adequate electric power supply had to be tackled in the face of such difficulties as the destruction of, or severe damage to, certain generating stations by enemy bombing, and the interruption of service due to the breakdown of the overhead wires of the Grid system. The large majority (about 73 per cent) of the faults on this overhead distribution system were caused by trailing cables of barrage balloons which had broken loose; and only some 14 per cent were directly attributable to enemy action. For strategic reasons it became necessary early in the War to effect a major transfer of munition works to South Wales and the south-west of England; and the resulting change in load distribution imposed a very onerous task on the national control organization of the Central Electricity Board. Having in mind the additional difficulties of obtaining materials, suitable coal and adequate labour, there can be no question that the successful operation of a system of public supply stations with an output in 1944 of more than 38,000 million $\mathrm{kWh}$., which was an increase of nearly one half on the 1939 output, is an outstanding performance.

As the supply of electric power for industrial purposes was a prime war-time necessity, so was the maintenance and extension of communications be- tween different parts of the country and overseas. In this field the British Post Office provided a vast private-circuit network for the operational, meteorological and administrative traffic of the Fighting and allied Services, and enlarged its peace-time trunk system to reduce delays in priority traffic concerned mainly with the supply of munitions. Much progress was made during the War in the equipment used on audio carrier current and coaxial cable systems with the object of making each circuit carry as many communication channels as possible. Where it was necessary or expedient, radio links operating on ultrashort wave-lengths were installed and used as an integral part of the land-line network. In spite of various precautions taken before and during the War, many disasters due to enemy action overtook the Post Office. For example, a single high-explosive bomb on the Old Bailey on May 10, 1941, severed 28 cables of different types and interrupted 5,200 working circuits, mainly long-distance.

Overseas communications for the Services, necessarily of a secret nature, were carried out mainly by the submarine cable system, a network of 155,000 nautical miles which suffered many vicissitudes during the War due to enemy action and other causes. The enormous quantities of Press traffic, etc., were mainly cleared on wireless circuits; and on the longdistance service an outstanding war-time technical development was the extension of relay working to avoid interruption of the service by unsuitable ionospheric conditions. Another remarkable development in British electrical engineering enterprise during the War was in connexion with the wireless transmission of photographs, drawings, etc. Although the whole of the London photo-telegraph apparatus was lost during the raids of May 1941, the number of circuits on which photographs can be transmitted. has been increased from three to eleven, and some two thousand facsimiles are now being exchanged monthly over direct circuits between London and the principal cities of the world.

The British broadcasting service was outstanding during the whole of the War in providing entertainment, news and stimulating programme items so necessary in keeping public morale at a high level. In addition, an important job, not perhaps adequately appreciated by British listeners, was carried out in providing listeners in the occupied countries of Europe with their only access to truth in news and their only means of contact with the world outside Nazi domination. As a result of the war-time efforts of our electrical engineers, Great Britain now possesses the world's largest long-wave broadcasting station, capable of delivering to the aerials a power of $800 \mathrm{~kW}$., as well as the world's largest short-wave broadcasting station, at which there are twelve transmitters, each capable of delivering $100 \mathrm{~kW}$. to one or other of the fifty-one directional beam aerials. In order to improve home reception and to provide for local broadcasting in the event of the interruption of communications due to invasion, the B.B.C. built sixty-four small broadcasting stations, which were synchronized and operated on one wave-length-an outstanding technical achievement. These were finally closed on July 28, 1945, when the Corporation changed over to the first instalment of peace-time broadcasting.

During his address, Dr. Dunsheath referred at some length to the development and applications of radar, both as a defensive and as an offensive instrument of war. This technique, developed first as a means of detecting attacking enemy aircraft, and later used 